\title{
Italo Calvino's Invisible Cities: A Fake Tourist Report and a True Literary Testimony
}

\section{Abstract}

Invisible Cities, Calvino's novel, or rather antinovel, is about very many things. It is actually one of the few literary attempts that have managed to palpably approach the realization of Mallarmé's ideal Book, into which the entire world would collapse. Consequently, it has attracted all kinds of interpretation, including sociological, urbanist, even political. Such practices have contributed to bypassing what Invisible Cities is in the first place: a linguistic artifact. Once appreciated as such, the (anti)novel starts opening up as language on language, and as literature on literature, which, according to the author of the article, is the novel's prime concern. Its self-referentiality is presented so condensedly and thoroughly (despite the modest size of the book) that the initiated reader will have made his journey through the fifty-five cities, woven together (precisely as a textus !) by the narrator's voice and the conversations between a fictional Marco Polo and an equally such Kublai Khan, with the feeling that both language and its expression closest to perfection, that is, literature, have been covered in all their crucial aspects. There are also correspondences with the various approaches and contributions of literary criticism. A secondary text the size of an article cannot illustrate them all, but making an imperfect - although representative - selection it can at least hope to succeed as an invitation to a systematic, and inspired, (re)reading of what the article signals as Calvino's most authoritative pronouncement, however invisible, on the world of his vocation.

Keywords: Invisible Cities, language, literary criticism, literature, reading, writing

\section{Introduction}


Since its publication in 1972 (Le città invisibili, Einaudi), Italo Calvino's (anti)novel Invisible Cities has been subjected to so many different, occasionally even opposite, readings that one is left with the feeling there is no interpretation that has not been tried. And at least once. Some seem genuine criticism, interested in the text itself. Others so obviously stretch the text in all conceivable and inconceivable directions, on a rack designed simply to make the text fit any of the preconceived theoretical frames or private agendas. The book has thus been approached from semiologic, structuralist, poststructuralist, and many other standpoints. The first reviews concentrated on seeing it as a grand instance of intellectual detachment, of the gap yawning between literature and its various world commitments (Mengaldo). It has been seen as a book of fables (Ravazzoli 224), an encyclopedia of the Calvinian imaginary (Barenghi 30), a rewriting of Marco Polo's cosmography of the East (Cannon 83), a modern (or, for yet others, postmodern) utopia stemming from the perception and the aesthetic abilities of the individual (e.g., Kuon; Scarpa), which was then even extended into a politically-minded reading: the novel is set in China, which at the time of its publication was ruled by Mao Zedong, considered by some Western progressives as the great creator of an ideal society (Weiss 145). The urban setting of the novel has attracted a great lot of interest, occasionally very literal. We can thus learn that the novel at times turns into a prophetic commentary on today's urban life, in an environment filled with computer-generated and electronically processed information (Cavallaro 77). For Letizia Modena, Calvino's texts, both fictional and non-fictional, have typically to do with "revitalizing urbanism in an era renowned for its singular mixture of upheaval and optimism" (1), with the "complexity of individual and communal perceptions of and interactions with the urban environment" (3-4). More aesthetically, Invisible Cities is a "serious, and beautiful, prose-poem about real problems in urban existence" (McLaughlin 108). Calvino's city is more generally read as a metaphor for life or, more accurately, for human society, a topos partly reaching back all the way to the Bible and Augustine's The City of God (Markey 6). Seen in the context of Calvino's engagement in the experimental literary group OuLiPo, Invisible Cities explores the interaction of verbal patterns with visual schemes, with mathematics and information theory, distortion, parody, the word and image interface (Ricci 106). Which brings us closer to reading Invisible Cities, a piece of literature, as literature. Angela M. Jeannet nicely combines Calvino's City as "both the outer and the inner 
cosmos, at the same time ever present reality in Marco Polo's memory and lost object of desire in his fantasy" (147) with reading it as "the analogue of language and storytelling" (148). In fact, Bernardini Napoletano's crucial study very early decided that the central problem of the book is actually the relationship between language and things (Bernardini Napoletano 195).

The present article is not only about recuperating Calvino's novel as literature, but in the first place about presenting it as a work of literature on literature (i.e., as metaliterary), both from the experiencing position of the writer (primary creation) and of the reader (secondary creation), on a scale that, in spite of my efforts to find a piece of criticism that would disprove me, has remained unnoticed.

\section{On the Invisibility of Some Cities}

In the case of Calvino's Invisible Cities, the most obvious intertext is II Milione, usually translated into English as The Travels of Marco Polo, allegedly dictated by the famous Venetian traveler to his coprisoner Rustichello da Pisa, romance writer, to keep them busy in a Genoan jail during the last months of the 13th century. Indeed, the very first sentence of Calvino's novel introduces both Polo and Kublai Khan, the Mongolian emperor of China and Polo's admiring employer:

Kublai Khan does not necessarily believe everything Marco Polo says when he describes the cities visited on his expeditions, but the emperor of the Tartars does continue listening to the young Venetian with greater attention and curiosity than he shows any other messenger or explorer of his. (Invisible Cities 5)

But this is also where the attentive reader stumbles for the very first time: if the Khan is not always certain that what Polo says of his empire is true, why does he prefer him over all other messengers and explorers in his charge? Truth does not seem to be the great Khan's priority. Does this mean that we as readers also need not expect facts on the cities to be presented? And what kind of cities are invisible cities in the first place!? In the traditional epic manner of in medias res the reader is immediately disqualified from reading the book with Baedeker expectations. Besides, the whole introductory passage beginning with the above quote is italicized, but the first specific description that follows it is in an unmarked font. One also notices that the introductory passage belongs to a 
narrating voice, while the description of the first city seems to come from Polo himself. Narratologically speaking, they are focalized in two different ways. Later on, a third level of exposition will be introduced so that we have to distinguish three separate narrative (or, again narratologically speaking, diegetic) levels:

the extradiegetic level, with an outside narrator observing and presenting Marco Polo and Kublai Khan;

the diegetic level proper, with Marco Polo and Kublai Khan conversing, which is the supposed here and now of the narrative, framing the ring composition of the book;

the hypodiegetic level, comprising the cities as presented by Polo to the Khan, which actually makes the bulk of the novel.

Not only do we not find this in a normal guidebook, but it is much more intricate than in historical Polo's book, too.

Travelogue expectations are betrayed in the very first sentence of the hypodiegetic part as well, which is only the second passage within the total of Calvino's novel: "Leaving there and proceeding for three days toward the east, you reach Diomira [...]" (Invisible Cities 7). This much will do. We immediately recognize historical Polo's rhetoric. For instance: "When you leave Locac and sail for 500 miles towards the south, you come to an island called PENTAM" (Polo, II, 534). But the similarity is deceitful. Only the second account really offers instructions as to how to reach Pentam. The one given by fictional Polo starts from a no-place, designated by there, an empty adverb of place - a 'shifter', to use Roman Jakobson's term - since there is nothing earlier in the text that could possibly be substituted by its pronominality. Historical Polo's point of orientation is very clear: Locac. What follows in fictional Polo's account is equally abortive: Kublai Khan learns one is to proceed to the east, for three days. Three days' walk? Ride? Historical Polo is again truly accurate: you sail, and even the not quite exactly expressing distance by time is refined into five hundred miles. Further, even if you do reach the slippery city of Diomira, what awaits you there are not historical Polo's stands with cloths and spices with prices duly mentioned, but "sixty silver domes, bronze statues of all the gods" (7) - you once again stop! Even if you accept the possibility of a fabulous city of sixty domes, all in silver, you remain puzzled by the statues of all the gods. All the 
gods of what pantheon? Of the religion Diomira supposedly subscribes to? A religion about which we have not learnt and will not learn anything? Of all the gods of the wider area? Or is it literally all the gods of mankind? Which is the most confounding idea of all. Calvino's "travelogue" is in fact not made of information, but of informational simulacra, even of plain misinformation. Facts are parodied into absurdities, reality into sheer fantasy: concerning the same Diomira we thus learn that it has "streets paved with lead, a crystal theater, a golden cock that crows each morning on a tower" (7). Invisible Cities is not another travelogue, but a parody of all of them, which in the first place means of the things these are interested in, of the way they look at them, and, especially to the point, of the way they recount them.

During the years I have been teaching Calvino's novel in my practical criticism class, an experience that has throughout made me increasingly sensitive to its literary autoreferentiality, I have also had the occasion times and again to realize how much this point has been missed by the past critical performance. Yes, it has been understood that what is at stake in the novel is the relationship between language and things. Yes, the highly problematic relationship between the author and the reader, the reader and the text, and between all three of them, has also been recognized. But how much there is of it, and of so many other things regarding the art of literature! First of all, you can - and should! - read every singly city for the sake of the imagination, and its organ, language, on their own. But you also can - and equally should! - amplify such reading by the metaliterary qualities of the text, a mine that has turned out for me to be anything but exhaustible. City by city - and one conversation of the two characters after another, as well as one narrator's "excursus" after another - the text opens up new considerations of literature as such, and year after year I have been able to lead my students with increasing ease through connecting the various accounts in the novel with the various aspects of the literary phenomenon, signaled by the various critical approaches of the past and present, in their own different ways. It is a missed opportunity not to recognize in Diomira's golden cock just cited the "artifice of eternity," the mechanical bird from Yeats's "Sailing to Byzantium." Intended or not, the intertextual reference is here for all to see and be reminded of the poem's theme: the permanence, and consequently greater reality, of art, versus the ephemerality, and consequently lesser reality of a merely outer world. 
It may sound totally unacceptable, but among many ways in which Invisible Cities can be tentatively defined one of the most cogent is certainly to see it as a manifesto of literature. The fact that this genre is typically written in garish, aggressive tones should not delude us. The novel (a bracketed prefix anti- or the inverted commas are here avoided as themselves garish in their repetition, but ought to be consistently implied) makes a point of both essential components of literature - language and imagination (in the Coleridgean sense of the power of seeing things afresh, and down to their essence, unlike the merely recombining capacity that is fancy)-as well as of the fact that the greater literature a work is, the less possible is it to distinguish the two. It defends the right of - or rather it promotes the need for - literature to be literature. If a literary work happens to be anything besides literature, this does not and cannot make it greater literature, as literature.

This is why Kublai Khan prefers Polo to his other employees. Because he feels attracted to the poetic function of language, instead to its communicative function (to use the superbly simple distinction of the Russian formalists). This is to say that every discourse, every way of using language, aims at conveying some information, located outside language, which is used only as the hardly avoidable means to express the information in question. Except the way of literature. Only in literature does language reflect on itself (in both meanings of reflection, as literal throwing back to itself and as contemplation). Structuralistically speaking, the signifier turns into the signified. Every linguistic usage is therefore concerned with some truth - a truth, the truth, Truth (and so is even lying, whose denial of truth is just the opposite extreme of being concerned with truth). Except literature. Truth, understood not metaphysically, of course - to which sense literature is a worthy contributor - but as objectively verifiable data of everyday life, is simply not literature's concern, a fact so difficult to swallow that Edgar Allan Poe was possibly the first Western poetician to expound it with sufficient explicitness, when he formulated the 'didactic heresy'. In his own way, Calvino echoes Poe's abruptness by beginning his novel with a negation. This is not visible from the English translation used here, but the original Italian reads "Non è detto che Kublai Kan creda a tutto quello che dice Marco Polo ...", which for our present needs could be translated as "Not that Kublai Khan necessarily believes everything Marco Polo says ..." The Khan is the reader; Marco Polo is the writer. Or Polo can be seen as the knowledgeable reader, and the Khan as the reader 
yet to be initiated into reading language not exploited as a ready-made conveyor of ready-made external meanings, but as a force eternally transforming shapes and forms, transforming in the process any world taken for granted, recreating all of them into its own.

In Invisible Cities Calvino keeps returning to the two diametrically opposite ways of using language, through the various cities Polo presumably visits. A nice example is Dorothea:

There are two ways of describing the city of Dorothea: you can say that four aluminum towers rise from its walls flanking seven gates with spring-operated drawbridges that span the moat whose water feeds four green canals which cross the city, dividing it into nine quarters, each with three hundred houses and seven hundred chimneys. And bearing in mind that the nubile girls of each quarter marry youths of other quarters and their parents exchange the goods that each family holds in monopoly - bergamot, sturgeon roe, astrolabes, amethysts - you can then work from these facts until you learn everything you wish about the city in the past, present, and future. Or else you can say, like the camel driver who took me there: "I arrived here in my first youth, one morning, many people were hurrying along the streets toward the market, the women had fine teeth and looked you straight in the eye, three soldiers on a platform played the trumpet, and all around wheels turned and colored banners fluttered in the wind. (9)

The first is the usual, communicative, informational way of using language as a means (or rather the means) to relate things: social, economic, historical... It is the way of the tourist guide, of the monograph, the brochure, the article and any book of instructions or recipes, all of them interested in describing and enumerating the outer reality. But there is also the way of the camel driver, turned in on himself, on itself, the way of inner vision, sustained by a language become private, intimate, very linguistic, as a matter of fact. Thus seen, the city of Dorothea becomes for the camel driver a source of true revelation (and dorothea actually is Greek for "gift of (the) $\operatorname{god}(\mathrm{s}) ")^{\left[{ }^{[1]}\right.}$ The revelation goes on and finishes as follows:

Before then I had known only the desert and the caravan routes. In the years that followed, my eyes returned to contemplate the desert expanses and the caravan routes; but now I know this path is only one of the many that opened before me on that morning in Dorothea. (Invisible Cities

9) 
Anyone intuiting the presence of metaliterature in Calvino's novel cannot overlook this and similar places as signals pointing to literature as a field of possibilities, especially as a field of manifold readings. They are invitations to Umberto Eco's concept of open (or multiple) against closed (or single) texts, that is of texts attracting and supporting different kinds of reading by loosening the omnipotent authority of the author and empowering a creative participation of the reader (see particularly Eco's The Role of the Reader: Explorations in the Semiotics of Texts and The Open Work). They invite considerations from the point of hermeneutics and historicism, that problematize levels of reading and contexts as guarantees of the text's unfixedness. Calvino's Polo actually believes that Kublai Khan, as his listener, also has a role to play in the narrator's stories so he urges him to take part in the narration. Elsewhere Calvino the essayist notes that

[t]he work will continue to be born, to be judged, to be destroyed or constantly renewed on contact with the eye of the reader. What will vanish is the figure of the author ... that anachronistic personage, the bearer of messages, the director of consciences. (The Uses of Literature 15-16)

Beno Weiss has already drawn attention to Calvino's pointing here to Roland Barthes's distinction between 'readerly' (lisible) texts, with a smooth, obvious, predetermined transition between the signifier and signified, based on well-defined habit, and 'writerly' (scriptible) texts, resistant to any given decoding and yet to be "finished," actually, by their readers' awareness of the highly imaginative writing-reading relationship and open participation in the creation of the text (131-32). The first can offer only pleasure (plaisir); it is the second that fills us with bliss (jouissance). Pretty much the same thing is expressed by Barthes's distinction between the 'irreversible' and 'reversible' texts (for all of this see Barthes's S/Z: An Essay and The Pleasure of the Text). For the means of achieving one or the other Calvino relies first of all on "the most complex and unpredictable" of all machines: "language" (The Uses of Literature 10). It is language, with its multiple workings, that is the principal structural element of the narrative in Invisible Cities, or, in A. J. Greimas's influential terminology, its true actant. What happens when language and the text it forms become fixed can be seen from the example of the city of Zora:

So the world's most learned men are those who have memorized Zora. But in vain I set out to visit the city: forced to remain motionless and always the same, in order to be more easily remembered, 
Zora has languished, disintegrated, disappeared. The earth has forgotten her. (Calvino, Invisible Cities 16)

Language become habit deadens the things it should express, or, in the poet's deep understanding, the things it should bring to full life. Calvino's plea for literature is a plea for language. Here is what ominously happens when approaching the town of Tamara:

You walk for days among trees and among stones. Rarely does the eye light on a thing, and then only when it has recognized that thing as the sign of another thing: a print in the sand indicates the tiger's passage; a marsh announces a vein of water; the hibiscus flower, the end of winter. All the rest is silent and interchangeable; trees and stones are only what they are. (Calvino, Invisible Cities 13; my emphasis)

The ominous here is the division of the world - that is, of language - into things which are themselves and things which only refer to other things - that is, into words treated in their own right, and words treated as merely signifying some signified outside themselves, which is equally already given. It gets even worse once you enter the city:

You penetrate it along streets thick with signboards jutting from the walls. The eye does not see things but images of things that mean other things: pincers point out the tooth-drawer's house; a tankard, the tavern; halberds, the barracks; scales, the grocer's.

Statues and shields depict lions, dolphins, towers, stars: a sign that something - who knows what? - has as its sign a lion or a dolphin or a tower or a star. Other signals warn of what is forbidden in a given place (to enter the alley with wagons, to urinate behind the kiosk, to fish with your pole from the bridge) and what is allowed (watering zebras, playing bowls, burning relatives' corpses). (Calvino, Invisible Cities 13)

Things cease being what they most evidently are: the particular things themselves. They are reduced to mere signals of other things, the only ones truly real and worthy. Being is degraded to representation. An image of the scales is not seen for what it literally is, before the encroachment of any kind of interpretation: an image, before anything else, of a known thing in the so-called real world, represented mimetically; which again metonymically stands for the grocer's shop, in the 
same world. An image, of the scales, equals a grocer's shop only at a second remove from its original meaning, which is itself. Again, this is what distinguishes literature from all other uses of language: it only is interested in words as words, not as substitutes to be automatically translated into as many things they simply stand for.

Calvino's plea is thus embedded in the very beginnings of modern literary criticism in the West, that is, in the Russian formalists' conception of estrangement or defamiliarization (ostranenie, in Russian). A writer truly aware of his or her tool makes the reader follow in his or her steps and stumble, stop at words as words, at images as images, which only secondarily happen to be also signs for something else. The lion on a shield is primarily not the lion as can be seen in a savannah, a zoo, or on TV, but an image, which is even not necessarily to be connected to its realworld prototype, but enjoyed for its two-dimensional stylization as such. In order to be able to enjoy words as words we have to estrange them from their automatized references, to be introduced to them, instead of inertly recognizing them. The introduction is to beings living in language, not in what we call the real world, of which they are then seen just as more or less unhappy acoustic or visual representations. Invisible Cities fights our inherent urge to "uncover" a "true" meaning from beneath its "seducing," "false" word, felt only as the former's conventionalized representative, in itself expendable. Language and its purest expression, literature, are to be accessed as something different from the world they supposedly convey, describe, imitate. Otherwise,

[h]owever the city may really be, beneath this thick coating of signs, whatever it may contain or conceal, you leave Tamara without having discovered it. Outside, the land stretches, empty, to the horizon; the sky opens, with speeding clouds. In the shape that chance and wind give the clouds, you are already intent on recognizing figures: a sailing ship, a hand, an elephant. (Calvino, Invisible

Cities 14)

Instead of seeing a cloud in all of its cloudness, you keep ignoring it, translating it into a ship, a hand, an elephant, all imported and grafted from outside.

There is one more significant detail in the description of Tamara, and we come across its variations throughout Invisible Cities. We read that, in the absence of any sign on a building, the building's "very form and the position it occupies in the city's order suffice to indicate its function" (13-14). 
Within the whole poetic economy of the novel, talking about the city as a structure built of its components also becomes a way to talk about the structuredness of the text (and in Calvino, once again just like in Roland Barthes, there is the tendency to see the world itself as a grand text). Kublai Khan himself rarely asks Polo about individual cities and seems more concerned with how these are related to one another, that is with the structural system, the pattern behind them, which, however, remains beyond detection. In describing the same city of Tamara Polo even goes as far as saying this pretty much explicitly: "Your gaze scans the streets as if they were written pages: the city says everything you must think, makes you repeat her discourse, and while you believe you are visiting Tamara you are only recording the names with which she defines herself and all her parts" (14; my emphasis).

The latter part of the above quote, and especially the part I italicized, points to yet another aspect of literature and reading it: to reading as the process of retracing the steps of the writing that preceded it. So, yes, Tamara may very well be a "post-humanist culturescape with no solid referents, but only signs leading not to meaning, but other signs," embodying an "almost obsessional decoding task" burdened with the necessity to detect signs everywhere (Cavallaro 73), but I argue that Tamara, too, just like any other of "Venice's fifty-five alter-egos" (Cavallaro 72), has first of all to be read as being about reading itself. About literature. In this particular instance, reading as a secondary creation, imposing itself on the sensitive and experienced reader ${ }^{[2]}$

The latter part of the quote also connects to the already hinted problem of the relationship between a surface (literal) and depth (interpretative) levels of a literary text. A good deal of Calvino's novel can thus be read as an elaboration on the notable words used by Joseph Conrad, another great storyteller, to describe the way in which Marlow, the storyteller of Heart of Darkness, used to tell stories:

[T]o him the meaning of an episode was not inside like a kernel but outside, enveloping the tale which brought it out only as a glow brings out a haze, in the likeness of one of these misty halos that sometimes are made visible by the spectral illumination of moonshine. (Conrad 8)

The inside-versus-outside moment in tales is not without implications that keep producing literary criticism along psychological lines. We read, for instance, that the city of Isaura knows of two forms 
of religion: "The city's gods, according to some people, live in the depths, in the black lake that feeds the underground streams. According to others, the gods live in the buckets that rise, suspended from a cable as they appear over the edge of the wells" (Calvino, Invisible Cities 20). The tension here is always between those for whom meanings in texts are to be derived from their writers' conscious level, from their intentions ("the buckets that rise"), and those for whom such a belief is only the so-called intentional fallacy and prefer to follow the origin of a text down to the writer's personal (in Freud's version) or even collective (in Jung's version) unconscious (from "the depths," in any case).

If we leave Tamara by a slightly different way - and there are multiple routes by which you can enter and exit all of the fifty-five cities, one can move through the text as one likes as soon as its rules have been mastered, which possibly makes it a reader's Bildungsroman (Springer 25), but akin to the matrix of a hypertext (Boyer 142) - and remain closer to the structural moment, we may arrive at Eudoxia, where "a carpet is preserved in which you can observe the city's true form" (Calvino, Invisible Cities 96). A carpet is woven, just as any text is, according to the very etymology of the word. This carpet "proves that there is a point from which the city shows its true proportions, the geometrical scheme implicit in its every, tiniest detail" (Calvino, Invisible Cities 96). In class, I have abundantly and with great ease used this city to illustrate both the paradoxical idea of the hermeneutic circle - you cannot understand the whole without understanding its parts, and you cannot understand the parts without understanding the whole built by its parts - and, derived from hermeneutics, Leo Spitzer's stylistic concept of the 'spiritual etymon' of a text, claiming that you can start from any phenomenon on the surface of its style and arrive at the inspiring center of the text.

There is an extremely important caveat that should be given at this point: Invisible Cities is not only about the creative glories of language. It is also about its impotence. On the one hand, as observed by Dani Cavallaro, it indicates that textual encoding ruins whatever is dear to us. The best thing then is to keep everything outside language. But then, language is unavoidable and it will always find a way to "recapture the contents of our thoughts" (Cavallaro 66). When the Khan asks "On the day when I know all the emblems ... shall I be able to possess my empire, at last?", Marco answers: "Sire, do not believe it. On that day you will be an emblem among emblems" 
(Calvino, Invisible Cities 22-23), and later adds that "the city must never be confused with the words that describe it" (61). Let me add that this happens the more you insist on the communicative, denotative, literal, hard character of language, instead of the poetic, connotative, suggestive, soft one. On the other hand, however, the said impotence means that even poetic language can only hint at the ultimate reality, never reach it. The ultimate reality is a sphere of total, perfect silence. Polo's images actually supplant the Khan's words, since these tend to communication, to stiffening absolute meanings ("Memory's images, once they are fixed in words, are erased" [Calvino, Invisible Cities 87] $)^{[3]}$ but what we read at the end of the description of the city of Olivia is also true: "Falsehood is never in words; it is in things" (62). These are poetic, imaginative words. Speaking of Don Quixote, Calvino elsewhere noted that "literary inventions are impressed on our memories by their verbal implications rather than by their actual words" (Six Memos 17). Words that implicate, rather than explicate, take us, readers/listeners, to the ultimate implicated word, the Word, which may be conveniently taken as a synonym for ultimate silence. There is a text behind every text, not just in an intratextual, superficial, sense, but first of all in the sense of a single text, the text, speechless beneath the covering of all the words. The idea is wellestablished in non-Western traditional literary criticism, while in the West it has been intuited rather by philosophers (Heidegger, Gadamer) and writers themselves (Hauptmann [his Urwort, the "protoword," resounding behind Worten, "words"], Rilke, Valéry), than by critics approaching literature from outside. In the poetics of Invisible Cities, this is first and foremost Marco's memory of his own, first, city, Venice, permeating his descriptions of all other cities.

To hear the protoword behind the words

is the power, sometimes called malignant, sometimes benign, that Anastasia, the treacherous city, possesses; if for eight hours a day you work as a cutter of agate, onyx, chrysoprase, your labor which gives form to desire takes from desire its form, and you believe you are enjoying Anastasia wholly when you are only its slave. (Calvino, Invisible Cities 12)

Now, this is writing truly enjoyable at its face value, but for anyone looking for "added values" I see no other way but recognizing in it yet another metamorphosis of the subject of literature, of writing and reading. The cutter organically translates forward (or backward?) into writer. The gems are the 
text(s) he works. The eight-hour labor is writing as his life's profession, while the desire is the inspiration, the writer's genuine urge making of his profession his vocation, actually (again in the etymological sense of being called to it). True writing happens only when giving form to desire becomes taking form from it, when the writer, as Heidegger uniquely put it, entspricht der Sprache, speaks off to speech (that is, answers language), "indem er auf ihren Zuspruch hört", by listening to its speaking to (that is, to its encouragement, or advice (Burwick 1436; my emphasis). Calvino formulates his own comment through the mouth of Marco Polo: "It is not the voice that commands the story: it is the ear" (Calvino, Invisible Cities 135). There are times when writing may look like a curse ("malignant," in the account of Anastasia), just as there are times when it seems a blessing ("benign"). In other words, it can both agitate and soothe, uplift and precipitate. In either direction, however, the final agent ought to be seen as the Great Writer, transcending every individual writer, yet another of Its slaves, Its mouthpieces, whose voices, the moment they are heard, are always already surpassed. Says the writer Silas Flannery, protagonist of another metanovel of Calvino's: "The only books I recognize as mine are those I must still write" (If on a Winter's Night 196).

\section{Conclusion}

Just as no chess player will ever live long enough to exhaust all the combinations of possible moves for the thirty-two pieces on the chessboard, so we know (given the fact that our minds are chessboards with hundreds of billions of pieces) that not even in a lifetime lasting as long as the universe would one ever manage to make all possible plays. (Calvino, The Literature Machine 8-9)

Later in Calvino's novel the movement of the chess pieces becomes the narrative of the invisible cities, each of the cities becoming another game (Calvino, Invisible Cities 121). The tension between the faith in a revelatory potential of language and a diffidence before its actual capacities is resolved in seeing language, and its literature, as play. Play not as sheer acrobacy, a time-killing diversion, but of the sort the universe with its entire existence is to God. Play, as the most disinterested human activity, comes closest to re-enacting the gratuitousness, the freedom of God's creation. In the world of language, the play takes the form of literature, the only use of language that has no ulterior, profit-minded motives. Midway through their conversation the Khan says to Marco: "From now on, I'll describe the cities to you, [and] in your journeys you will see if 
they exist" (Calvino, Invisible Cities 69). The tables have been turned. Oscar Wilde's saying that life imitates art far more than art imitates life is being revindicated. It is language that creates the world, not the other way round.

It may be difficult for an article of this size to convincingly make its point - based on years of my own and my students' experiences - in which case I can only refer the reader back to the text itself, which should always be the first and last point of reference. For myself I can here only reassert, with more forcefulness, that Invisible Cities is, first of all, the beautiful linguistic texture one reads through, word by word, consecutively or not. It subscribes to Heidegger's Bewahrung of a work of art, keeping-in-trust, letting it be itself, instead of it staying for something else, as a mere allegory of an allegedly true meaning. Only as such can a work of art disclose the being of beings (see especially Heidegger's The Origin of the Work of Art). Marco Polo's original, historical text is interested in the travelled lands. Calvino's is interested in the text. Not in travelling, but in writing about travelling, which is not an exoteric movement through outer spaces, but an esoteric gliding through their imaginative recreation. Only at a third level can for Calvino's Marco Utopia be "a method, his personal means of forming the perfect city for himself" (Christensen 27). Prior to that, however, it is the writer's work on the perfect text, in all its unattainability. Only peripherally is the city of Fedora about postmodern existence and its tempo, about "the alarming flux that undermines confidence in self and community today" (Markey 77). Its non-literal meanings, however, must start from literature as a realm of possibilities, of the different paths of its realization, both in writing and reading, "the forms the city could have taken if, for one reason or another, it had not become what we see today", where "every inhabitant visits [Fedora's museum], chooses the city that corresponds to his desires" (Calvino, Invisible Cities 32). Divergent are also the results that writers themselves, these most imaginative readers, have come to, but Salman Rushdie's conclusion that Invisible Cities is not "really a novel at all, but a sort of fugue on the nature of the City" (Rushdie 16), true as it may be at its own level, is surely inferior to John Updike's that it is "a metaphor for the artistic experience" (Updike 462). Historical Polo's book is easy to illustrate and its front cover typically looks like this ${ }^{[4]}$

While Calvino's version typically looks like this: 
Invisible Cities is an extremely carefully woven text, on texts, the best of postmodernism in its need to write about writing, and read about reading. 


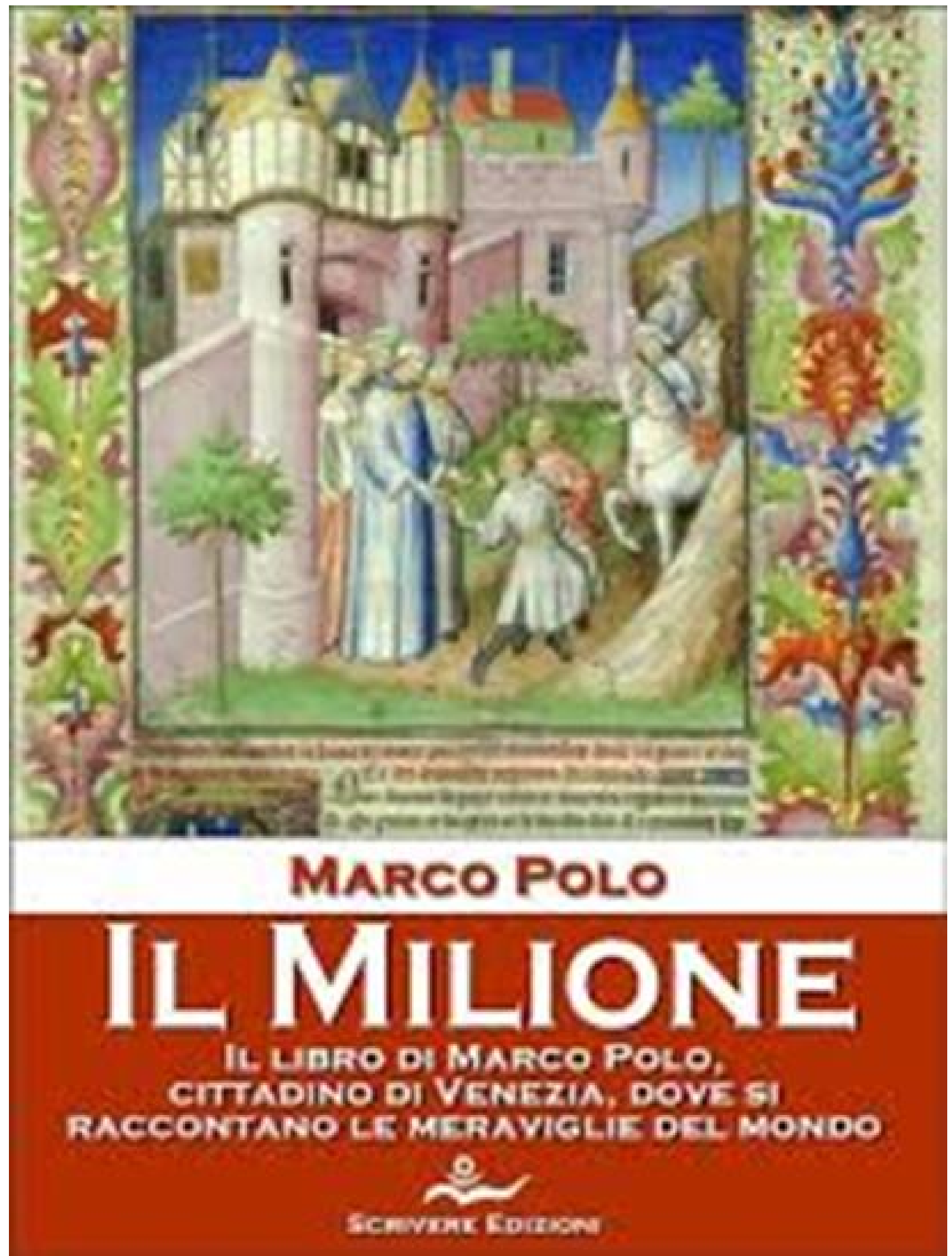



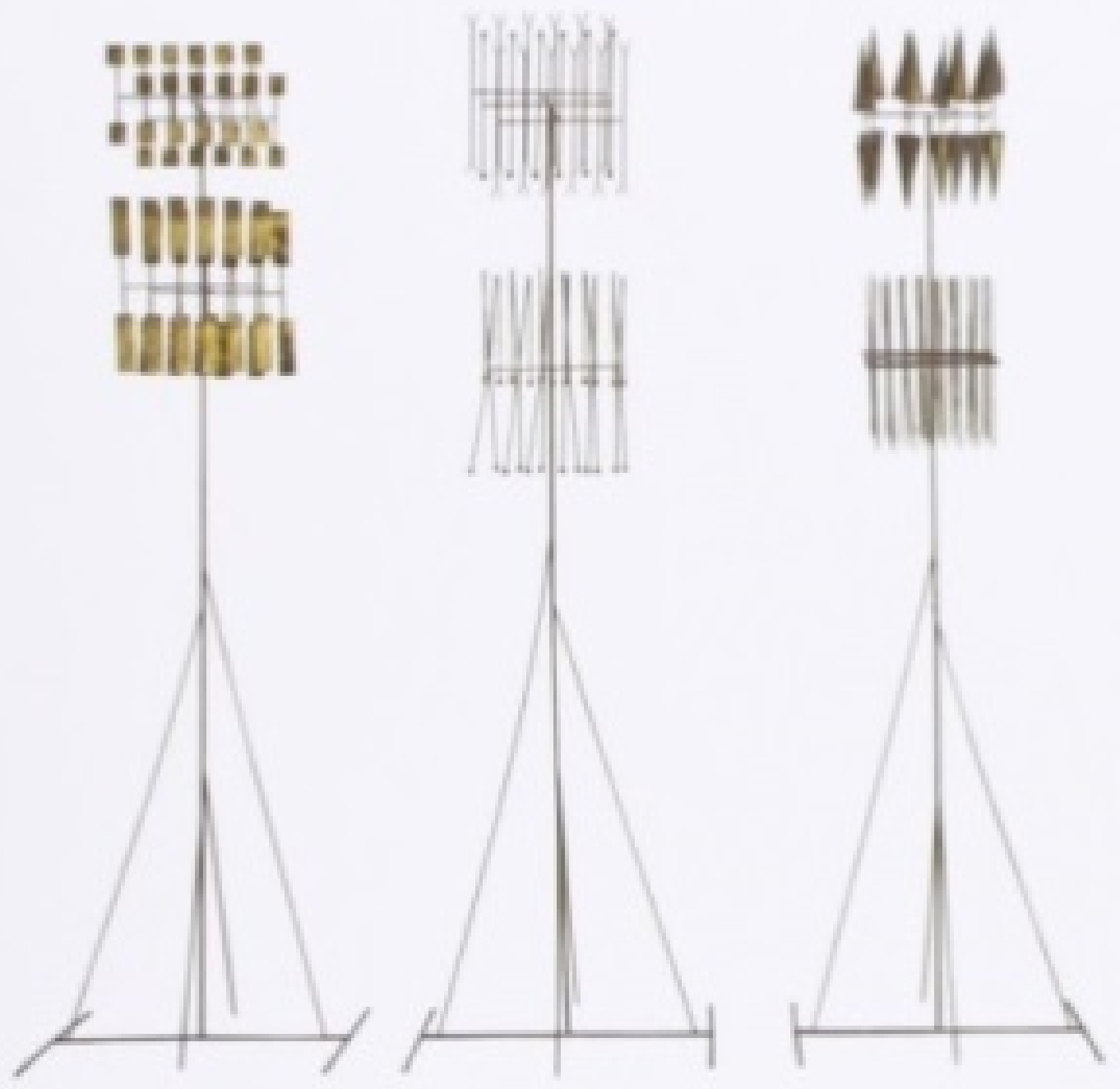

\section{Italo Calvino / Le città invisibili}


Its prime concern is language, and the linguistic, literary insight that though the city, the world, is not literature, it still is possible - actually, pressing - to read it as a text.

\section{Works Cited}

Barenghi, Mario. "La forma dei desideri: l'idea di letteratura di Calvino." Italo Calvino Newyorkese, edited by Anna Botta and Domenico Scarpa, Avagliano, 2002, pp. 27-40.

Bernardini Napoletano, Francesca. I segni nuovi di Italo Calvino: da Le cosmicomiche a Le città invisibili. Bulzoni, 1977.

Boyer, M. Christine. CyberCities: Visual Perception in the Age of Electronic Communication. Princeton Architectural, 1996.

Burwick, Frederick. "Translation." The Encyclopedia of Romantic Literature, edited by Frederick Burwick, vol. 1, Wiley-Blackwell, 2012, pp. 1435-39.

Calvino, Italo. If on a Winter's Night a Traveler. Translated by William Weaver, Houghton Mifflin Harcourt, 2012.

Calvino, Italo. Invisible Cities. Translated by William Weaver, Harcourt Brace \& Company, 1974.

Calvino, Italo. The Literature Machine. Translated by Patrick Creagh, Secker and Warburg, 1987.

Calvino, Italo. Six Memos for the Next Millennium. The Charles Eliot Norton Lectures: 1985-86, Harvard University Press, 1988.

Calvino, Italo. The Uses of Literature: Essays. Translated by Patrick Creagh, Harcourt Brace, 1986.

Cannon, Joan. Italo Calvino: Writer and Critic. Longo, 1981.

Cavallaro, Dani. The Mind of Italo Calvino: A Critical Exploration of His Thought and Writings. McFarland \& Company, 2010.

Christensen, Peter G. "The Utopian Vision.” Italo Calvino. Bloom's Major Short Story Writers, edited by Harold Bloom, Chelsea House Publishers, 2002, pp. 26-28. 
Conrad, Joseph. Heart of Darkness. Penguin Books, 1973.

Fussell, Paul. 1982. Abroad: British Literary Traveling between the Wars. Oxford University Press, 1982.

Jeannet, Angela M. 2000. Under the Radiant Sun and the Crescent Moon: Italo Calvino's Storytelling. University of Toronto Press, 2000.

Kuon, Peter. "Critica e progetto dell'utopia: Le città invisibili di Italo Calvino." La visione dell'invisibile: Saggi e materiali su Le città invisibili di Italo Calvino, edited by M. Barenghi, Gianni Canova, and Bruno Falcetto, Mondadori, 2002, pp. 24-41.

Markey, Constance. Italo Calvino: A Journey toward Postmodernism. University Press of Florida, 1999.

McLaughlin, Martin L. Italo Calvino. Edinburgh University Press, 1998.

Mengaldo, Pier Vincenzo. La tradizione del Novecento: da D’Annunzio a Montale. Milan: Feltrinelli, 1975.

Modena, Letizia. Italo Calvino's Architecture of Lightness: The Utopian Imagination in an Age of Urban Crisis. Routledge, 2011.

Polo, Marco. The Book of Ser Marco Polo, the Venetian, Concerning the Kingdoms and Marvels of the East. Translated by Henry Yule, revised by Henri Cordier, J. Murray, 1903.

Ravazzoli, Flavia. "Le città invisibili di Calvino: utopia linguistica e letteratura." Strumenti critici: Rivista Quadrimestrale di Cultura e Critica Letteraria, vol. 53, 1987, pp. 193-201.

Ricci, Franco. Painting with Words, Writing with Pictures: Word and Image in the Work of Italo Calvino. University of Toronto Press, 2001

Rushdie, Salman. "Calvino." London Review of Books, 17-30 Sept. 1981, pp. 16-17.

Scarpa, Domenico. "Sguardi dal ponte: Le città invisibili come autobiografia di un dopoguerra." Italo Calvino: les mots, les idées, les rêves, edited by Denis Ferraris and Mario Fusco, U de la Sorbonne Nouvelle, 2005, pp. 213-31. 
Springer, Carolyn. "The Reader's Role." Italo Calvino. Bloom's Major Short Story Writers, edited by Harold Bloom, Chelsea House Publishers, 2002, pp. 24-25.

Updike, John. Hugging the Shore: Essays and Criticism. Knopf, 1983.

Weiss, Beno. Understanding Italo Calvino. University of South Carolina Press, 1993. 
[1] The difference comes close to the difference made in travel literature criticism between the travel guide and the travel log (see, for instance, Fussell 67, 202-03).

[2] This always happens within any reader's specific 'horizon of expectation', to use a term from $\mathrm{H}$. $R$. Jauss's reception theory, which in practice is never completely open and so defines (precisely in the etymological meaning of limiting) every reader's possibilities of interpretation. Here is one of the ways Calvino puts it: "Each city receives its form from the desert it opposes; and so the camel driver and the sailor see Despina, a border city between two deserts" (Invisible Cities, 18).

[3] Only in time does Marco learn the native tongue and is able to shape his "travelogue" in words, "[b]ut you would have said communication between them was less happy than in the past; to be sure, words were more useful than objects and gestures in listing the most important things of every province and city - monuments, markets, costumes, fauna and flora - and yet when Polo began to talk about how life must be in those places, day after day, evening after evening, words failed him, and little by little, he went back to relying on gestures, grimaces, glances" (Calvino, Invisible Cities 38-39).

[4] The book covers are here reproduced for nonprofit purposes, in strict terms of fair use. They can be found at the publishers' homepages https://www.facebook.com/scrivereedizioni/ and https://www.oscarmondadori.it/ respectively.

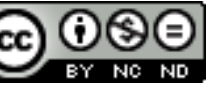

Creative Commons Attribution-NonCommercial-NoDerivatives 4.0 International License 